\title{
Experimental Behavior of Partially Prestressed High Strength Concrete Beams
}

\author{
Shady H. Salem, Khalid M. Hilal, Tarek K. Hassan, Ahmed S. Essawy \\ Department of Structural Engineering, Faculty of Engineering, Ain Shams University, Cairo, Egypt \\ Email: shady.salem@bue.edu.eg \\ Received July 2013
}

\begin{abstract}
In the last few decades, prestressed concrete has been rapidly used in bridge engineering due to the enormous development in the construction techniques and the increasing need for long span bridges. High strength concrete has been also more widely spread than the past. It currently becomes more desirable as it has better mechanical properties and durability performance. Major defect of fully prestressed concrete is its low ductility; it may produce less alarming signs than ordinary reinforced concrete via smaller deflection and limited cracking. Therefore, partially prestressing is considered an intermediate design between the two extremes. So, combining high strength concrete with partial prestressing will result in a considerable development in the use of prestressed concrete structures regarding the economical and durability view points. This study presents the results of seven partially prestressed high strength concrete beams in flexure. The tested beams are used to investigate the influence of concrete compressive strength, prestressing steel ratio and flange width on the behavior of partially prestressed beams. The experimentally observed behaviors of all beams were presented in terms of the cracking load, ultimate load, deflection, cracking behavior and failure modes.
\end{abstract}

Keywords: Partially Prestressed; High Strength Concrete Beams; Serviceability Behavior; Failure Modes

\section{Introduction}

In the last few decades, prestressed concrete has been rapidly used in many fields of structural engineering, especially in the field of bridge engineering due to the enormous development in the construction techniques and the increasing need for long span bridges. Now more than 50 percent of bridges all over the world are constructed using prestressing techniques [1]. High strength concrete has been also more widely spread than the past due to the enormous development in the material technology and the greater demand for high strength concrete which leads to a better quality control for concrete [2]. Therefore, it currently becomes more desirable due to its better mechanical properties and durability performance.

Fully prestressed concrete may result in a less significant camber at service load than the specified design one. The camber can also increase due to creep of the concrete with respect to time [3]. Another major defect of fully prestressed concrete is its low ductility, where it is stiffer than the ordinary reinforced concrete so it may produce less alarming signs than ordinary reinforced concrete via smaller deflection and limited cracking [4]. Therefore, partially prestressing is considered an intermediate design between the two extremes [3]. For these reasons, partially prestressed became a desirable struc- tural solution worldwide. High strength concrete was also believed to have lower flexural ductility than ordinary concrete. However, some researches had proved that the ductility of the high strength concrete was still increasing when flexural stresses were applied [5]. So, combining high strength concrete with partial prestressing will result in a considerable development in the use of prestressed concrete structures regarding the economical and durability view points.

This paper presents an experimental investigation to assess the behavior of partially prestressed high strength concrete beams. The effects of various parameters have been investigated. These parameters are the concrete compressive strength, prestressing steel ratio and the concrete flange width. In the remaining sections of this paper, the experimental program will be thoroughly discussed. The results will be enumerated and comparisons to highlight behavior characteristics will be presented.

\section{Experimental Program}

\subsection{Specimens’ Details}

The experimental program was conducted on seven partially prestressed concrete beams with total length of $4800 \mathrm{~mm}$. The beams were simply supported with 4500 $\mathrm{mm}$ clear span and $150 \mathrm{~mm}$ projection at each end. All 
the beams were $150 \mathrm{~mm}$ wide and $250 \mathrm{~mm}$ deep for all the five rectangular sections. The web of the T-section specimens was similar to the rectangular ones while flange widths were 350 and $550 \mathrm{~mm}$. All the beams were reinforced using closed stirrups of $10 \mathrm{~mm}$ diameter with spacing $100 \mathrm{~mm}$ for the first $1400 \mathrm{~mm}$ and $200 \mathrm{~mm}$ for the rest of the beam. Also all the beams were reinforced using two ordinary longitudinal reinforcement of $10 \mathrm{~mm}$ diameter as a top and bottom reinforcement with $25 \mathrm{~mm}$ cover. The end zone was reinforced by extra stirrups for the first $300 \mathrm{~mm}$ with stirrup spacing of $50 \mathrm{~mm}$. Three square stirrups were used around each tendon to act as anti-bursting reinforcement. Figure 1 shows the specimen's typical reinforcement details while Table $\mathbf{1}$ gives the specimen details.

\subsection{Material Properties}

Three different concrete mixes where designed so as to reach 40, 70, $90 \mathrm{MPa}$ cubic compressive strength at 28 days. Numerous trial batches have been developed to reach the required strength. Finally, the concrete mixtures were produced at a concrete central batch plant. The average 28-days cube compressive strength for the three batches were 42, 95 and $114 \mathrm{MPa}$. The prestressing strands of $1860 \mathrm{~N} / \mathrm{mm}^{2}$ tensile strength, $1670 \mathrm{MPa}$ yield strength and 200,000 MPa elastic modulus were used. All conventional reinforcement whether the longitudinal or transverse reinforcement were also of nominal tensile strength of $400 \mathrm{MPa}$.

\subsection{Instrumentation}

Figure 2 illustrates the instrumentation used with the test setup. Four linear variable displacement transducers (LVDT) were used to monitor the deflection across the length of the beams. The concrete top surface strain and the bottom reinforcement strains were measured using electrical strain gauges. All the readings of the LVDT's and the strain gauges were automatically recorded via a data acquisition system at each loading step using LabView program. The crack propagation was also monitored during the test up to failure.

\subsection{Test Setup and Loading Procedure}

The beams were tested under quasi-static load using four point loading scheme. The applied loads were $1400 \mathrm{~mm}$ far from the supports leaving $1800 \mathrm{~mm}$ of a constant moment zone. Figure 3 shows a photograph of the test setup. The load was applied up to $80 \%$ of the calculated cracking load then released. This cycle is repeated one more time. After that, another two cycles were achieved by reaching the first visible crack(s) then releasing. Finally the load was reapplied incrementally to failure. The aim of the first two cycles was to ensure the behavior linearity before cracking, while the other two cycles were to study the behavior of the beams after stiffness reduction due to cracking. Figure 4 illustrates the schematic loading path for the concrete beams.

\section{Experimental Results}

\subsection{Test Observations}

The cracking behavior of the tested partially prestressed beams was examined within the constant moment zone. Generally, it was observed that all cracks initiated at the

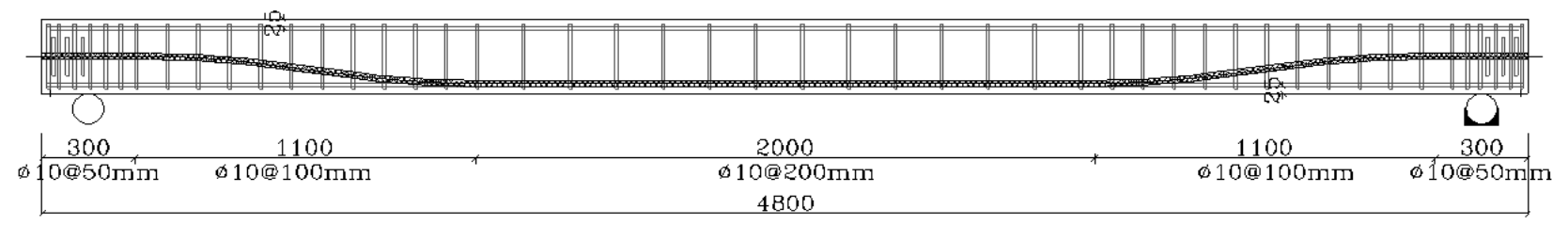

Figure 1. Specimen's typical reinforcement details.

Table 1. Specimen details.

\begin{tabular}{|c|c|c|c|c|c|}
\hline $\begin{array}{l}\text { Specimen } \\
\text { Code }\end{array}$ & $\begin{array}{c}\text { Cross Section } \\
\text { Type } \\
\end{array}$ & $\begin{array}{c}\text { Number of } \\
\text { Prestressing Steel Cables }\end{array}$ & $\begin{array}{c}\text { Prestressing Steel } \\
\text { Ratio (\%) } \\
\end{array}$ & $\begin{array}{c}\text { Concrete Compressive } \\
\text { Strength (MPa) }\end{array}$ & $\begin{array}{c}\text { Study } \\
\text { Parameter }\end{array}$ \\
\hline $\mathrm{R}-0.264-70$ & $\mathrm{R}$ & $1(12 \mathrm{~mm})$ & 0.264 & 85 & Control \\
\hline R-0.264-90 & $\mathrm{R}$ & $1(12 \mathrm{~mm})$ & 0.264 & 101 & Concrete compressive strength \\
\hline R-0.373-70 & $\mathrm{R}$ & $1(12 \mathrm{~mm})$ & 0.373 & 85 & Prestressing reinforcement ratio \\
\hline R-0.528-70 & $\mathrm{R}$ & $2(14 \mathrm{~mm})$ & 0.528 & 85 & Prestressing reinforcement ratio \\
\hline $\mathrm{T}-0.264-70 *$ & $\mathrm{~T}$ & $1(12 \mathrm{~mm})$ & 0.264 & 85 & Flange width $(\mathrm{b}=350)$ \\
\hline $\mathrm{T}-0.264-70 * *$ & $\mathrm{~T}$ & 1 & 0.264 & 85 & Flange width $(\mathrm{b}=550)$ \\
\hline
\end{tabular}



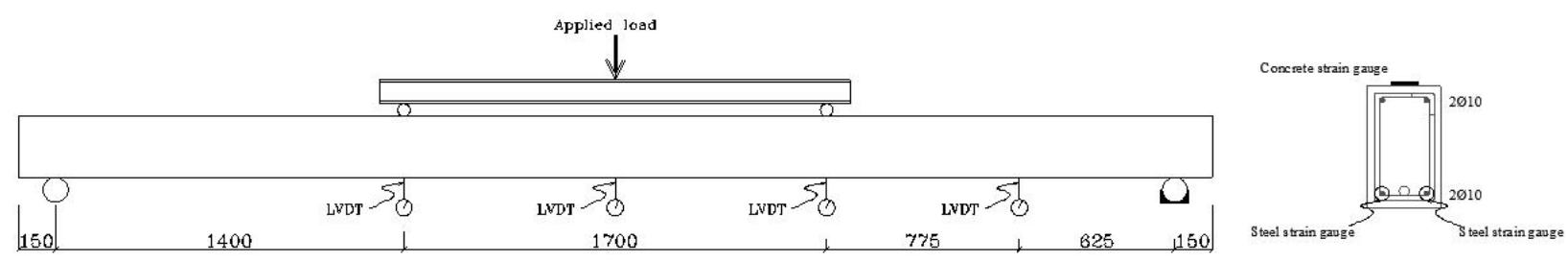

Figure 2. Instrumentation used to monitor the behavior during testing.

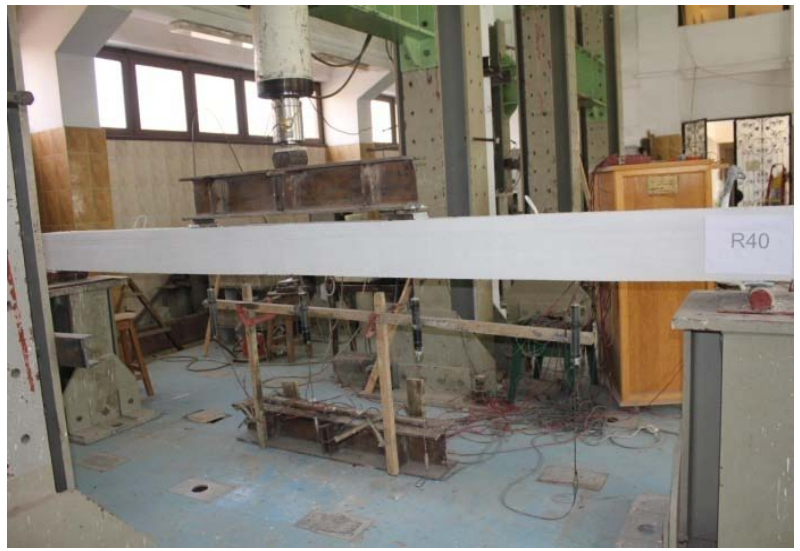

Figure 3. Test setup.

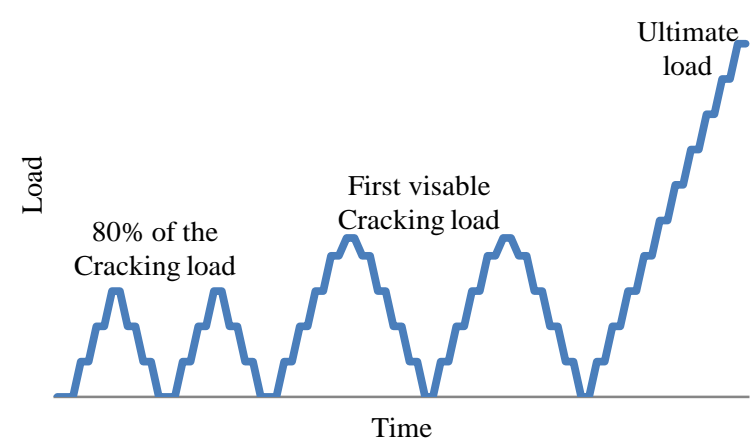

Figure 4. Schematic loading path for the concrete beams.

constant moment zone started perpendicular to the center line of the beam. It was also observed that the stirrups acted as crack initiators for most of the flexural cracks. On the other hand, Table 2 shows cracking load $\left(\mathrm{P}_{\mathrm{cr}}\right)$, ultimate load $\left(\mathrm{P}_{\text {ult }}\right)$ and their corresponding mid-span deflection in addition to the failure mode for each of the tested beam. Figure 5, however, depicts photograph of a typical concrete crushing failure mode.

\subsection{Load-Deflection Behavior}

It was noticed that the load-deflection response of all the tested beams acted linearly during the loading and unloading of the first two cycles prior cracking, while it appeared in a parabolic manner after cracking which might be encountered due to the non-linear behavior of the stress-strain behavior of the prestressing strands [1].
Table 2. Beam capacities and mode of failure.

\begin{tabular}{|c|c|c|c|c|c|}
\hline $\begin{array}{l}\text { Specimen } \\
\text { code }\end{array}$ & $\begin{array}{c}\mathrm{P}_{\mathrm{cr}} \\
(\mathrm{MPa})\end{array}$ & $\begin{array}{c}\Delta_{\mathrm{cr}} \\
(\mathrm{mm})\end{array}$ & $\begin{array}{c}\mathrm{P}_{\text {ult }} \\
(\mathrm{MPa})\end{array}$ & $\begin{array}{c}\Delta_{\text {ult }} \\
(\mathrm{mm})\end{array}$ & $\begin{array}{l}\text { Failure } \\
\text { mode }\end{array}$ \\
\hline R-0.264-70 & 26.9 & 6.7 & 61.3 & 80.2 & $\begin{array}{l}\text { Concrete } \\
\text { crushing }\end{array}$ \\
\hline R-0.264-40 & 24.9 & 10.5 & 59.7 & 109.4 & $\begin{array}{l}\text { Concrete } \\
\text { crushing }\end{array}$ \\
\hline R-0.264-90 & 27.4 & 5.7 & 65.2 & 127.0 & $\begin{array}{l}\text { Concrete } \\
\text { crushing }\end{array}$ \\
\hline R-0.373-70 & 30.4 & 7.4 & 73.7 & 65.3 & $\begin{array}{l}\text { Concrete } \\
\text { crushing }\end{array}$ \\
\hline $\mathrm{R}-0.528-70$ & 35.2 & 9.5 & 84.6 & 77.8 & $\begin{array}{l}\text { Concrete } \\
\text { crushing }\end{array}$ \\
\hline $\mathrm{T}-0.264-70^{*}$ & 23.6 & 4.4 & 67.8 & 146.6 & $\begin{array}{l}\text { Concrete } \\
\text { crushing }\end{array}$ \\
\hline $\mathrm{T}-0.264-70^{* *}$ & 35.1 & 4.7 & 60.1 & 58.1 & $\begin{array}{l}\text { Prestressing } \\
\text { rupture }^{+}\end{array}$ \\
\hline
\end{tabular}

+ The loading stopped at a safe load level based on the ultimate load calculations before expected prestressing strand rupture

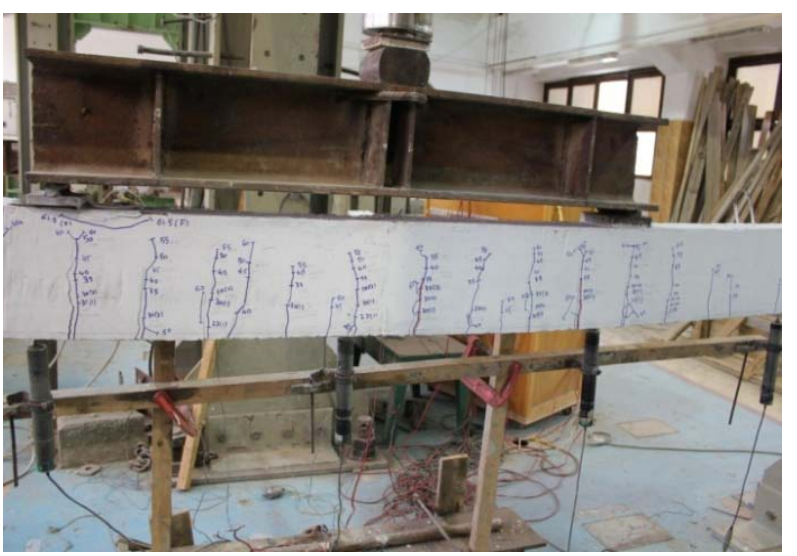

Figure 5. Typical compression failure due to concrete crushing at the face of applied load.

Figure 6 shows the typical load versus central deflection behavior encountered in the prestressed beams during the first four cycles while Figure 7 illustrates the effect of the studied parameters on the load-deflection behavior. From the given graphs in Figure 7, it can be concluded that concrete compressive strength significantly affects the deflection behavior prior to cracking. It should also be noted that after cracking, high strength concrete exerts a slightly higher stiffness than normal strength concrete 


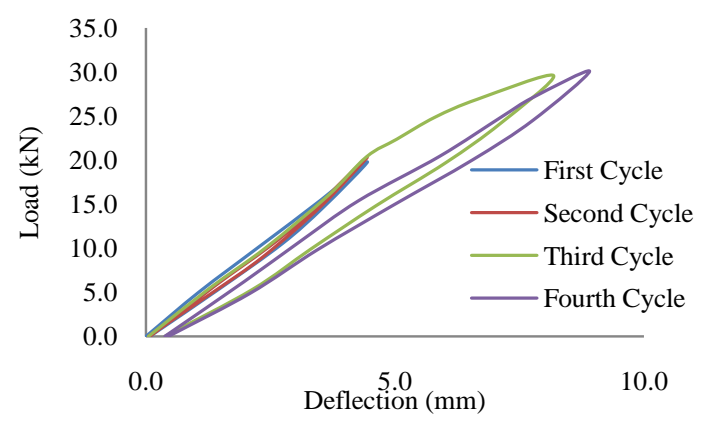

Figure 6. Magnified load-deflection behavior at the first four cycles for beam (R-0.264-70).

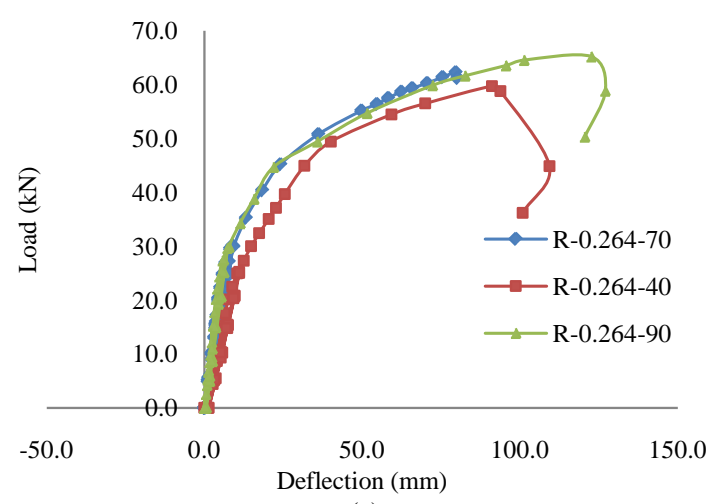

(a)

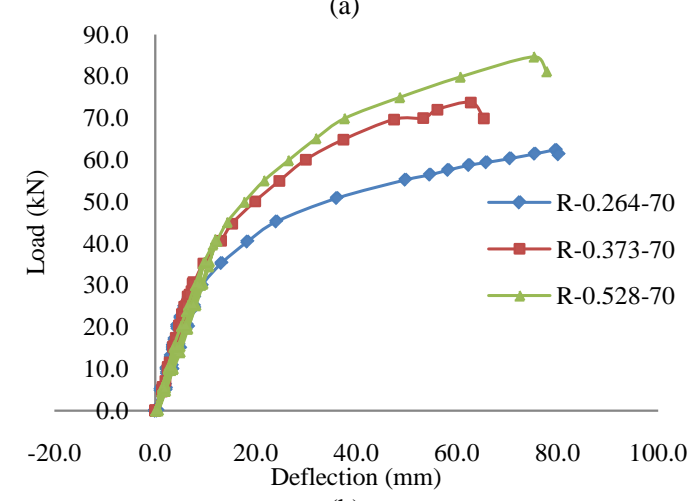

(b)

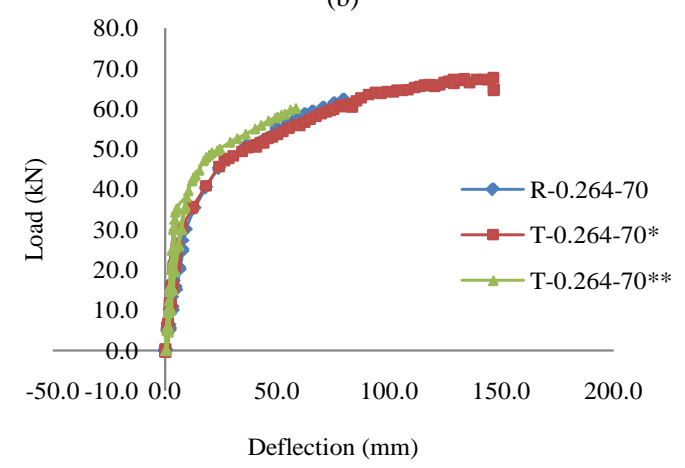

(c)

Figure 7. Load-deflection behavior for the tested beams under several studied parameters; (a) Beam with different concrete compressive strength; (b) Beam with different prestressing steel ratio; (c) Beam with different compression flange width. which agrees with other researchers who studied the behavior of high strength concrete beams subjected to pure flexure with no axial load [6]. Increasing the prestressing steel ratios didn't increase the beams' stiffness prior to cracking but significantly increase its' stiffness after cracking. As the flange width increase, the stiffness of the tested beams prior to cracking increase due to the change in the gross inertia, while after cracking, the effect of the flange width was not concluded as the loading of the largest flange width stopped before failure so as not to reach the prestressing strand rapture. But it can be observed that the flange width slightly influence the loaddeflection response after cracking.

\subsection{Crack Pattern}

The cracking behavior was observed along the constant moment zone at different loading stages from first cracking to ultimate load. Figure 8 shows the propagation of the average crack width with respect to the ratio of applied to ultimate load. From these graphs, the effect of the studied parameters can be easily detected. As the concrete compressive strength increases, the average crack width increases at the same load level and vice versa. It was also observed that the effect of prestressing reinforcement ratio on the average crack width is negligible at the same normalized load level (if the load level was measured as a ratio of the ultimate load for each beam). In other words, at $50 \%$ of the ultimate load for any beam, the average crack widths were approximately equal but as the prestressing steel ratio increases the ultimate load increases. So at a certain load, as the prestressing steel ratio increases the average crack width decreases. It was also observed that the average crack width increase as the compression flange width increase. This finding can be encored to the higher location of the neutral axis so as to balance with the tension force in the reinforcement at a given top load level. Figure 9 shows the average crack propagation height with respect to the ratio of applied to ultimate load. It was observed that the concrete compressive strength and the effective flange width affect the average the crack height the same way of affecting the crack width, which could be a result of the slight increase of the neutral axis above beam bottom fibers for high strength concrete compared to the higher increase in the normal strength concrete. On the other side, the prestressing steel ratio was directly proportional to the average crack height. Figure 10 shows the relation between the average crack spacing versus the ratio of applied to ultimate load. From this figure, it could be concluded that at early loading stages, the concrete compressive strength is in a directly proportional relation with the average crack spacing while it become of insignificant effect at the final loading stages. It was also 


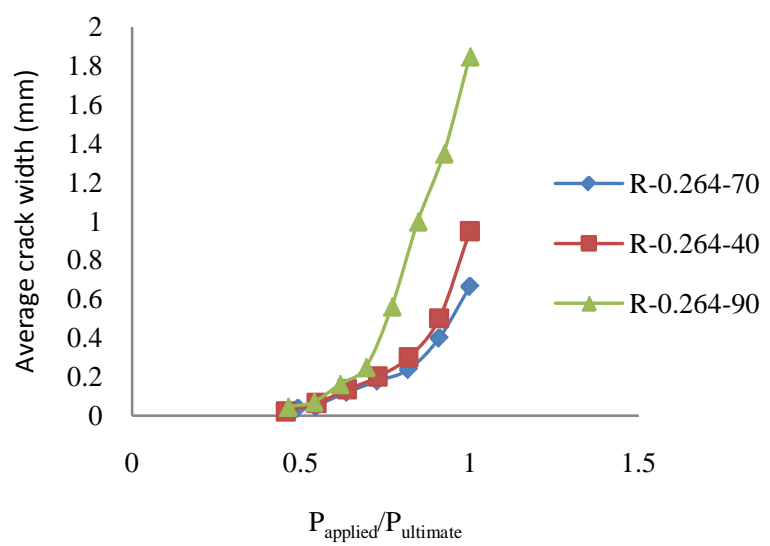

(a)

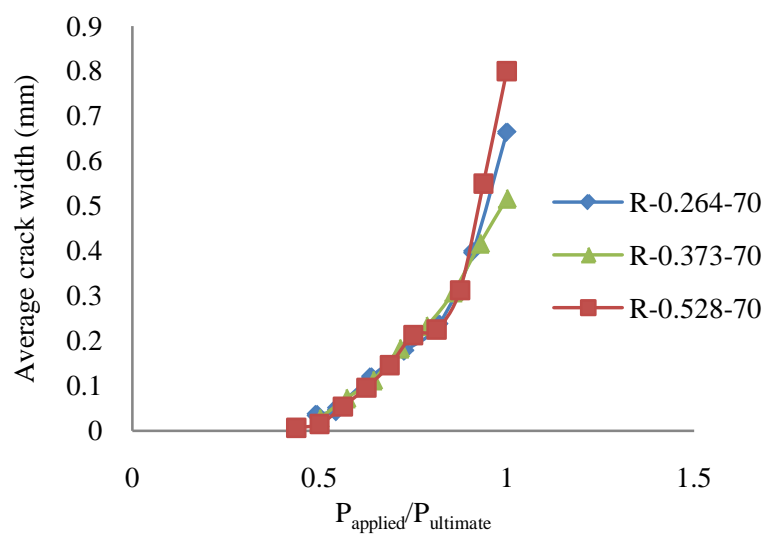

(b)

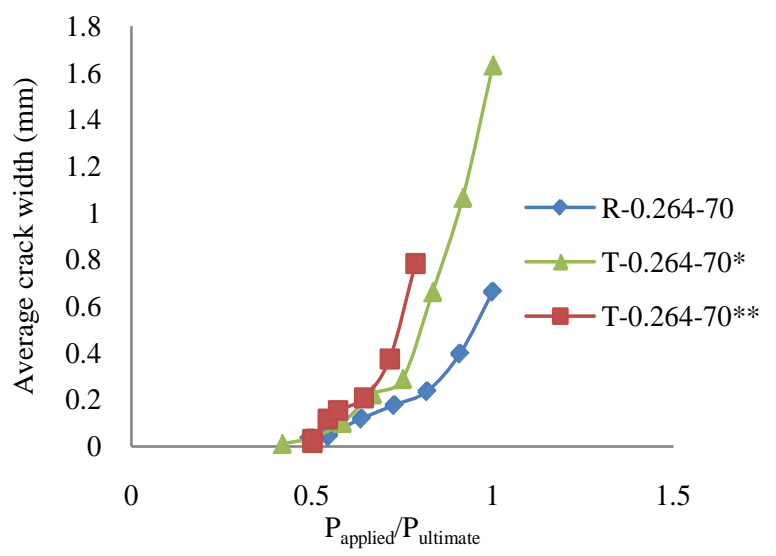

(c)

Figure 8. Average crack width at different loading levels; (a) Beam with different concrete compressive strength; (b) Beam with different prestressing steel ratio; (c) Beam with different compression flange width.

concluded that as the prestressing steel ratio increases the average crack spacing increases. Finally, the average crack width is directly proportional to the flange width. In other words, as the compressive flange width increases, the cracks tend to widen and propagate rather than forming new cracks.

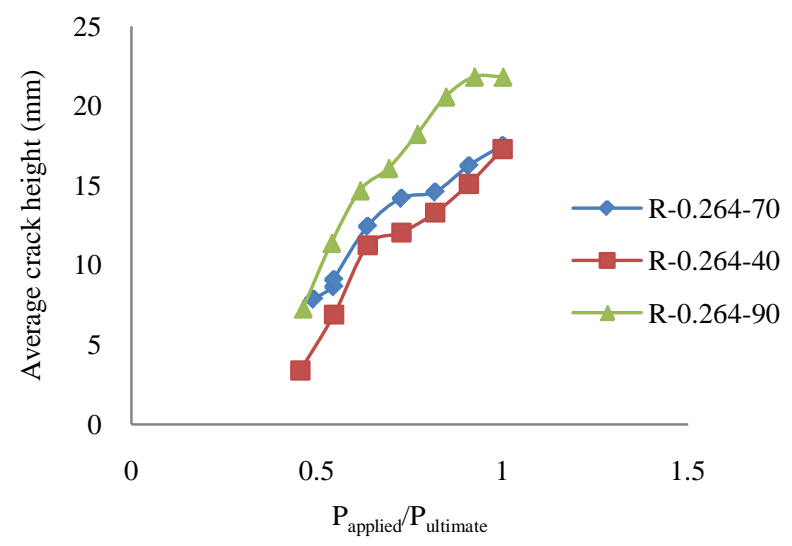

(a)

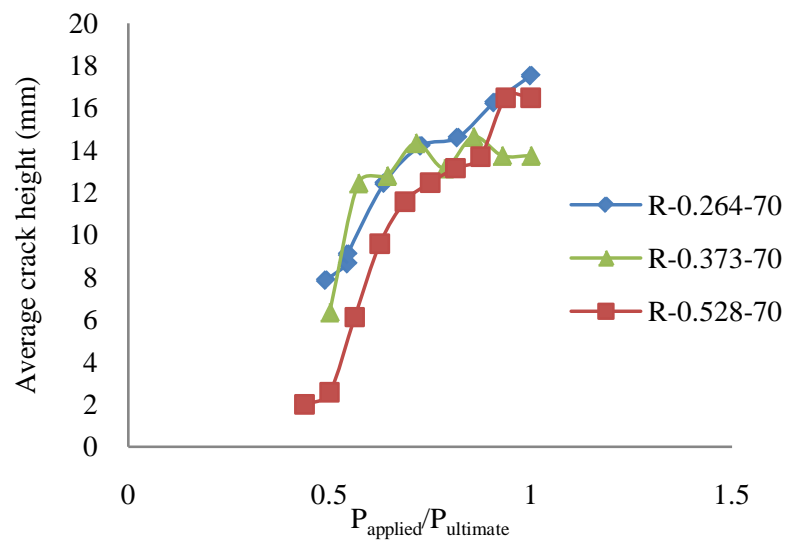

(b)

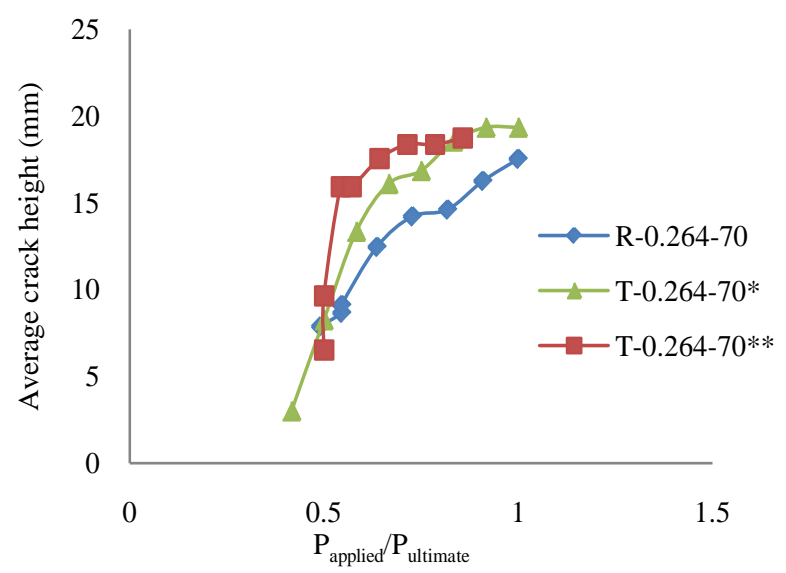

(c)

Figure 9. Average crack height at different loading levels; (a) Beam with different concrete compressive strength; (b) Beam with different prestressing steel ratio; (c) Beam with different compression flange width.

\subsection{Ultimate Strain}

The top compressive strain in the tested beams was monitored from the beginning of loading up to failure. Figure 11 shows the influence of changing the concrete compressive strength and the prestressing steel ratio on 


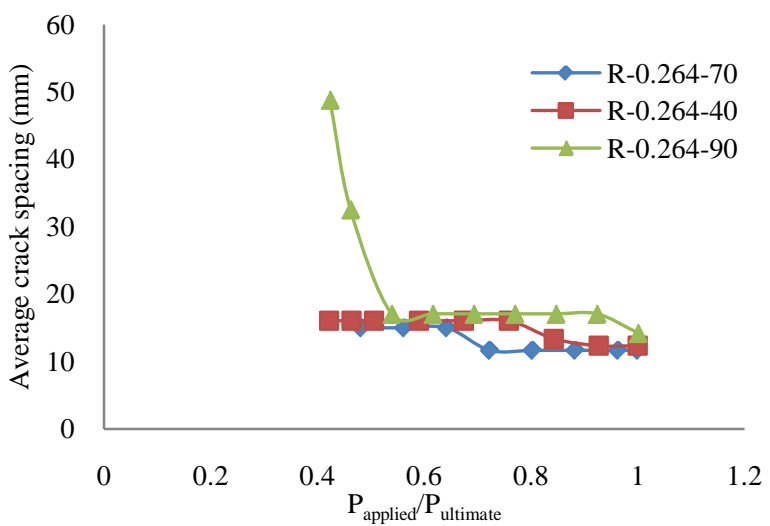

(a)

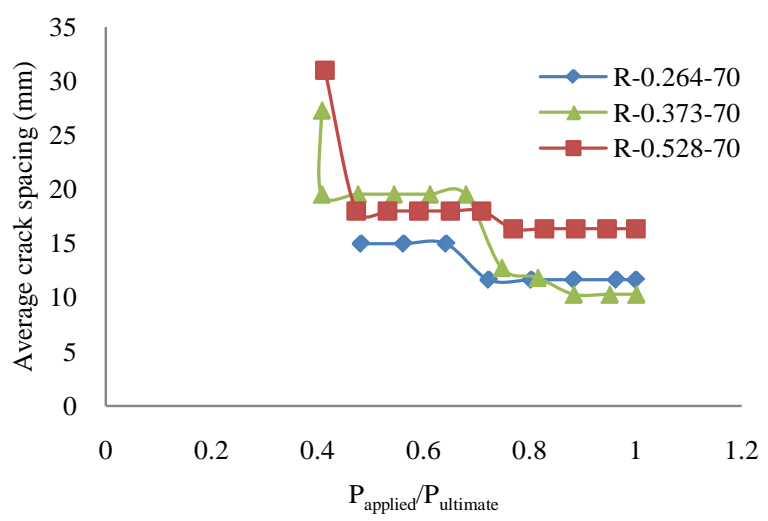

(b)

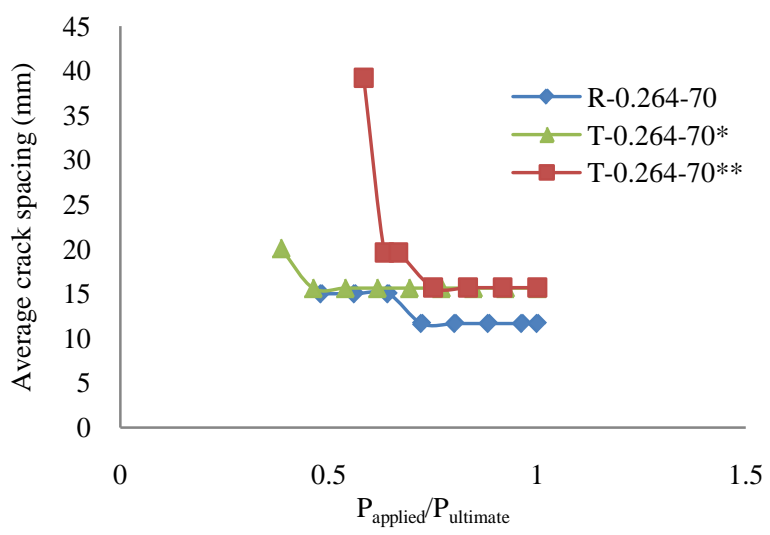

(c)

Figure 10. Average crack spacing at different loading levels; (a) Beam with different concrete compressive strength; (b) Beam with different prestressing steel ratio; (c) Beam with different compression flange width.

the ultimate compressive strength. It is obvious that the ultimate compressive strain is directly proportional to concrete compressive strength, while it is inversely proportional to the prestressing steel ratio. From this figure, it could be concluded that the ultimate compressive strain value specified for normal strength concrete might be conservative for high strength concrete. Moreover, the

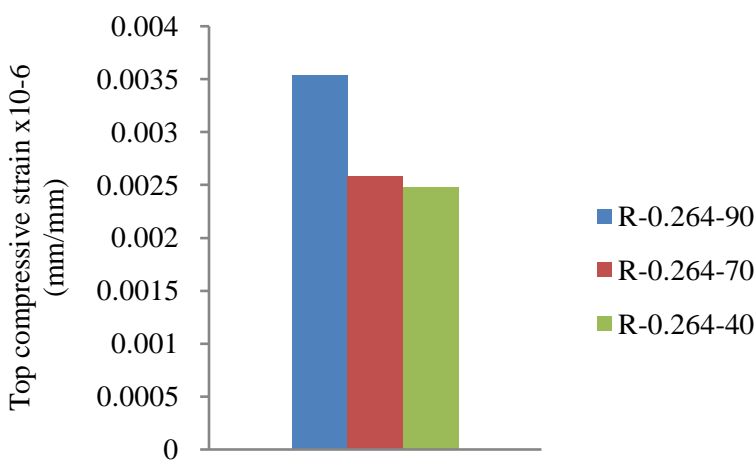

(a)

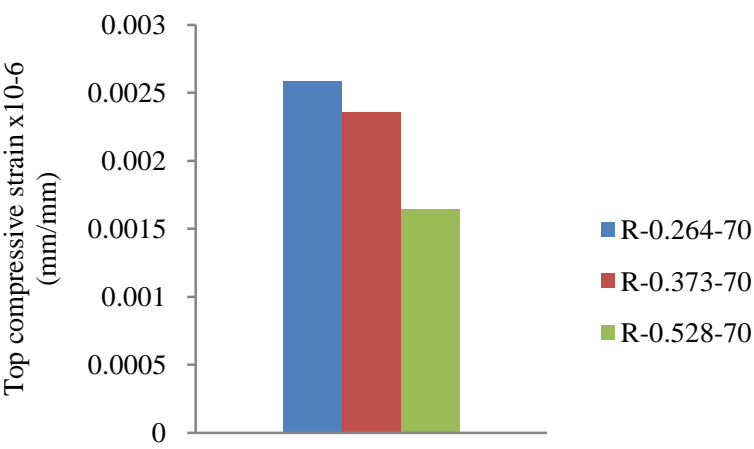

(b)

Figure 11. Ultimate compressive strain with respect to different parameters. (a) Beam with different concrete compressive strength; (b) Beam with different prestressing steel ratio.

prestressing steel ratio influences the ultimate strain for the high strength partially prestressed concrete beams, which can be encored for the high ductility achieved in prestressed concrete beams using higher prestressing steel ratio.

\section{Conclusions}

From the observations of the experimental work reported here above for partially prestressed concrete beams, the following conclusions could be drawn:

- Increasing the concrete nominal strength from 42 to $114 \mathrm{MPa}$ led to an increase at the cracking load by $10 \%$ while its' corresponding deflection decreased by $45 \%$. Also the ultimate load increased by $9.2 \%$ whereas its corresponding deflection increased by $16 \%$.

- As the concrete compressive strength increases the average crack width decreases while the average crack height increases at the same load level.

- The prestressing steel ratio had a negligible effect on the average crack width at early load levels compared to the ultimate load. However, the ultimate load significantly increases with increasing the prestressed steel ratio. So at the same load as the prestressed steel ratio increased the average crack width decreased. 
- The compression flange width is directly proportional to the average crack height and width. While it is inversely proportional to the average crack spacing.

- The ultimate compressive strain in concrete increased by $42 \%$ by increasing the concrete compressive strength from 42 to $114 \mathrm{MPa}$ achieving $0.0035 \mathrm{~mm} / \mathrm{mm}$.

- The prestressing steel ratio had a great influence on the ultimate compressive strain, as doubling the prestressing steel ratio led to a $36 \%$ reduction in the concrete ultimate strain.

\section{REFERENCES}

[1] M. Collins and D. Mitchell, "Prestressed Concrete Structures,” Prentice Hall, Englewood Cliffs (NJ, USA), 1991.

[2] ACI Committee, 363, "State-of-the-Art Report on High
Strength Concrete,” (1992 (Reaproved 1997)), pp. 1-37.

[3] A. A. Abdelrahman, "Serviceability of Concrete Beams Prestressed by Fiber Reinforced Plastic Tendons," Ph.D. Thesis, University of Manitoba, Manitoba, 1995.

[4] Y. Zandi, Y. Akgün and A. Durmuş, "Investigating the Use of High Performance Concrete in Partially Prestressed Beams and Optimization of Partially Prestressed Ratio," Indian Journal of Science and Technology, 2012, pp. 2991-2996.

[5] H. Manalip, M. Pinglot and M. Lorrain, "Behavior of the Compressed Zone of Reinforced and Prestressed High Strength Concrete Beams," ACI Journal, Vol. 149, 1994, pp. 209-226 (SP149-12).

[6] S. W. Shin, K. Ghosh and J. Moreno, "Flexural Ductility of Ultra-High-Strength Concrete Members," ACI Structural Journal, Vol. 86, No. 4, July/Aug., 1989, 39 p. 